\title{
Yogurt - a potential strategy for overcoming lactose intolerance: the significance of the dose
}

\author{
Jogurt - potencjalna strategia w nietolerancji laktozy: znaczenie dawki
}

\author{
Edyta Mądry', Beata Krasińska², Małgorzata Woźniewicz³, Sławomira Drzymała-Czyż, Waldemar Bobkowski', \\ Teresa Torlińska1, Jarosław Walkowiak ${ }^{3,4}$ \\ 1Department of Physiology, Poznan University of Medical Sciences, Poland \\ 2Department of Hipertensiology, Angiology and Internal Diseases, Poznan University of Medical Sciences, Poland \\ 3Department of Dietetics, Chair of Human Nutrition and Hygiene, Poznan University of Life Sciences, Poland \\ ${ }^{4}$ Department of Pediatric Gastroenterology and Metabolic Diseases, Poznan University of Medical Sciences, Poland \\ 5Department of Pediatric Cardiology and Nefrology, Poznan University of Medical Sciences, Poland
}

Przegląd Gastroenterologiczny 2012; 7 (2): 81-86

DOI: $10.5114 / p g .2012 .28649$

Key words: yogurt, lactose intolerance, breath test, hypolactasia.

Słowa kluczowe: jogurt, nietolerancja laktozy, test oddechowy, hipolaktazja.

Address for correspondence: Edyta Mądry MD, PhD, Department of Physiology, Poznan University of Medical Sciences, 6 Swiecickiego, 60-781 Poznan, Poland, phone: +48 501728 956, e-mail: edytamadry@poczta.onet.pl

\begin{abstract}
Introduction: Adult-type hypolactasia (ATH) is the most common enzyme deficiency in humans. Incomplete digestion of lactose may result in lactose malabsorption (LM) causing symptoms of lactose intolerance (LI).

Aim: Determination the dose of lactose, administered as a single serving in the form of yogurt, that is tolerated by $\mathrm{LI}$ healthy young adults.

Material and methods: All (10 young adults) subjects were homozygotes C/C at locus 13910 upstream of the LCT gene. The hydrogen-methane breath test (BT) was performed after a load of 400, 200 and $100 \mathrm{ml}$ of yogurt ( 5 h). Clinical symptoms were assessed for $12 \mathrm{~h}$.

Results: Ingestion of $400 \mathrm{ml}$ of yogurt brought about abnormal BT results in all examined individuals; consumption of $200 \mathrm{ml}$ did so in two of ten subjects, while a load of $100 \mathrm{ml}$ caused borderline hydrogen excretion in one individual. However, residual fermentation of lactose was observed for several hours in all subjects. All participants reported symptoms after the ingestion of $400 \mathrm{ml}$ of yogurt and their severity was significantly higher than that observed after a load of $200 \mathrm{ml}$ After consuming $100 \mathrm{ml}$ of yogurt, none of the examined individuals reported gastrointestinal symptoms.

Conclusions: Subjective observation of clinical symptoms sug gests that young adult LI may tolerate up to $200 \mathrm{ml}$ of yogurt served in one meal. However, when considering the objective assessment of LM by BT, it seems that the dose served per meal definitely should not exceed $100 \mathrm{ml}$.
\end{abstract}

\section{Streszczenie}

Wstęp: Hipolaktazja typu dorosłych jest najczęstszym niedoborem enzymatycznym występującym u ludzi. Niepełne trawienie laktozy może prowadzić do zaburzeń jej wchłaniania, co powoduje zespół objawów klinicznych określanych jako nietolerancja laktozy (NL).

Cel: Określenie dawki laktozy podawanej jednorazowo w postaci jogurtu, tolerowanej przez zdrowe młode osoby dorosłe z NL. Materiał i metody: Badaniem objęto 10 młodych dorosłych z NL. Wszyscy badani byli homozygotami -13910 C/C w zakresie genu promotorowego laktazy. U każdej osoby wykonano wodorowo-metanowy test oddechowy (TO) po obciążeniu 400, 200, $100 \mathrm{ml}$ jogurtu (5 godzin). Objawy kliniczne oceniano przez 12 godzin po spożyciu każdej dawki produktu.

Wyniki: Nieprawidłowe wyniki TO występowały u wszystkich badanych osób po spożyciu $400 \mathrm{ml}$, a u 2 spośród 10 po spożyciu 200 ml jogurtu. Obciążenie dawką 100 ml skutkowało graniczną wartością TO u 1 osoby. U wszystkich badanych stwierdzono resztkową fermentację laktozy przez wiele godzin (mediana sumy wydalania wodoru i metanu w 240. min testu $-6,5$ ppm). Wszyscy badani zgłaszali objawy kliniczne po spożyciu $400 \mathrm{ml}$ jogurtu. Ich nasilenie było istotnie większe niż obserwowane po obciążeniu $200 \mathrm{ml}$ produktu. Dawka $100 \mathrm{ml}$ jogurtu nie wywołała dolegliwości brzusznych ani zmiany konsystencji stolca u żadnej spośród badanych osób.

Wnioski: Subiektywna obserwacja objawów klinicznych sugeruje, że młodzi dorośli z NL mogą tolerować do $200 \mathrm{ml}$ jogurtu podawanego $w$ jednym posiłku. Uwzględniając jednak obiektywną ocenę zaburzeń trawienia laktozy za pomocą TO, wydaje się, że jednorazowa dawka zdecydowanie nie powinna przekraczać $100 \mathrm{ml}$. 


\section{Introduction}

The National Institute of Diabetes and Digestive and Kidney Diseases of the NIH (USA) states that about 4 billion people worldwide cannot digest lactose, the main disaccharide of milk, and thus may not be able to absorb a sufficient amount of calcium from dairy products [1]. This indicates that their small intestinal lactase (LCT [MIM 603202]) activity is only a small fraction of the infantile level, not allowing for unlimited digestion of lactose throughout the course of a lifetime. Incomplete digestion of lactose may result in lactose malabsorption (LM), a condition in which undigested lactose may reach the colon, causing symptoms of abdominal pain, bloating, flatulence, cramps, and diarrhea, forming a syndrome known as lactose intolerance (LI) [2].

Recently it has been shown that the genotype $\mathrm{C} / \mathrm{C}$ of the LCT promoter gene is responsible for predisposition to adult-type hypolactasia (ATH) [3]. The ATH is an inherited autosomal recessive trait leading to decreased LCT activity in the intestinal mucosa after weaning and it is thought to be the most common cause of milk intolerance in children, adolescents and adults, and the most common enzyme deficiency in humans overall [4]. Eliminating dairy products from the diet or limiting their consumption is the strategy taken by many $\mathrm{LI}$ individuals to avoid the associated abdominal discomfort. However, such a diet usually contains less calcium and vitamin D than the recommended daily intake and may lead to poor health outcomes, particularly in relation to bone mineral density and the risk of fractures $[5,6]$. It is known, however, that most LI subjects can tolerate some amount of lactose and that the lactose ingested in fermented dairy products is better tolerated than that in milk [7-9]. Moreover, the calcium content in yogurt is much higher than in milk (415 mg for plain, low-fat yogurt vs. $285 \mathrm{mg}$ for semi-skimmed milk, respectively, in one cup) [10].

\section{Aim}

The objective of the present study was to determine the cut-off point of a lactose dose, administered as a single serving in the form of yogurt, that is tolerated by $\mathrm{LI}$ healthy young adults.

\section{Material and methods}

Ten highly motivated, clinically symptomatic, otherwise healthy young adults with $\mathrm{LI}$ were enrolled in the study. The investigated group consisted of 5 women and 5 men, all of Caucasian descent, aged 20-25 years (median: 23.0 years), with body mass index (BMI) ranging from $19 \mathrm{~kg} / \mathrm{m}^{2}$ to $25 \mathrm{~kg} / \mathrm{m}^{2}$ (median: $22.0 \mathrm{~kg} / \mathrm{m}^{2}$ ). All of the enrolled participants reported symptoms indicative of lactose intolerance prior to the study.
A predisposition to ATH was confirmed by molecular analysis; all subjects were homozygous $\mathrm{C} / \mathrm{C}$ at locus $13910(-13910 \mathrm{C} / \mathrm{C})$ upstream of the LCT gene (NM_005915.4:c.1917+326C >T; rs4988235). For -13910 T>C polymorphism detection, the kit MutaGEL Lactase (Immundiagnostik AG, Bensheim, Germany) was used. The details of applied methodology have been described elsewhere [11].

Lactose malabsorption was confirmed in all study participants based on a hydrogen-methane breath test (BT) with a load of $25 \mathrm{~g}$ of lactose, following an overnight fast. More specifically, subjects were instructed not to eat or drink for at least $12 \mathrm{~h}$ before the test and to avoid slowly digested foods, including beans and other legumes, brans or high-fiber cereals, on the day before the test. Participants were not allowed to smoke, sleep or exercise vigorously for at last $1 \mathrm{~h}$ before or at any time during the test. Breath samples were collected at baseline (fasting) and every 30 min within the $3 \mathrm{~h}$ after the ingestion of lactose. The samples were analyzed with QuinTron MicroLyser DP Plus (Quintron, USA). A positive $B T$ was defined as a breath $\mathrm{H}_{2}$ level increase of at least $20 \mathrm{ppm}$ over the lowest preceding value within the test period, or a breath $\mathrm{CH}_{4}$ level increase of at least $12 \mathrm{ppm}$ over the baseline within the test period, or as a combined increase $\left(\mathrm{H}_{2}\right.$ and $\left.\mathrm{CH}_{4}\right)$ of at least $15 \mathrm{ppm}$ within the test period.

After selection of the study group, a BT was performed three times in each of the subjects (with intervals of at least 7 days) after a load of 400, 200, $100 \mathrm{ml}$ of yogurt as a single serving given as a drink (lactose content 19.2 g, 9.6 g, 4.8 g respectively). Breath samples were collected at baseline (fasting) and 30, 60, 90, 120, 150, 180, 210, 240, 270 and 300 min after lactose-containing product ingestion. The excretion of gases is expressed as the sum of hydrogen and doubled methane expiration.

Clinical symptoms were assessed within the $12 \mathrm{~h}$ after each product load using the questionnaire adopted for the project. The issues addressed were:

1) abdominal pain (0 - abdominal pain did not occur/1 discomfort/2 - mild pain/3 - pain impeding normal functioning/4 - unbearable pain),

2) number of stools ( 0 - no stool/ 1, 2, 3... - corresponded to the number of stools),

3) stool consistency ( 0 - formed/1 - mushy or compressed $/ 2$ - loose/3 - liquid),

4) intestinal rumbling (0 - lack/1-- barely perceptible/2 moderately severe/3 - very severe).

In addition, the BT area under the curve (AUC) was calculated assuming that it reflects semi-quantitatively the production of the total amount of intestinal gases over the 5-h period. All values are expressed as median ( $1^{\text {st }}-3^{\text {rd }}$ quartile). 
Statistical analysis of the data was performed using the Kruskal-Wallis test with post-hoc comparisons.

\section{Ethical consideration}

The protocol of the investigation was approved by the Ethical Committee of the Poznan University of Medical Sciences, Poland (150/11). Written informed consent was obtained from all subjects.

\section{Results}

The comprehensive data of BT after loading with 400, 200 and $100 \mathrm{ml}$ of yogurt are shown in Table I. Nine subjects exhaled exclusively hydrogen, while in one individual the excretion of methane was also found. There were no significant differences in the fasting breath hydrogen/methane levels between the three doses of product. They did appear after lactose loading, reaching a level of significance at 90 min into the test. Ingestion of $400 \mathrm{ml}$ of yogurt brought about abnormal BT results in all examined individuals. Consumption of $200 \mathrm{ml}$ of yogurt resulted in abnormal BT results in two of ten subjects, while a load of $100 \mathrm{ml}$ caused a borderline rise (20 ppm) of hydrogen excretion in one subject. However, residual fermentation of lactose was observed for several hours in all subjects (median value of hydrogen and methane excretion in 240 min was 6.5 ppm)

The values of hydrogen/methane AUC for various yogurt doses differ significantly $(p<0.00001)$. AUC values for $400 \mathrm{ml}$ of yogurt (186.5 ppm $\times \mathrm{h}$ [143.5-195.5 ppm $\times \mathrm{h}$ ]) were significantly higher than for $200 \mathrm{ml}(74.0 \mathrm{ppm} \times \mathrm{h}$ [61.5-100.9 ppm $\times \mathrm{h}])$ and $100 \mathrm{ml}(26 \mathrm{ppm} \times \mathrm{h}$ [19.4-45.5]);
( $p<0.029$ and 0.00001, respectively). A tendency towards statistical difference between the loads of 100 and $200 \mathrm{ml}$ of yogurt was observed $(p<0.098)$.

All examined subjects reported symptoms after the ingestion of $400 \mathrm{ml}$ of yogurt. The severity of symptoms was significantly higher than that observed after a load of $200 \mathrm{ml}$. After consuming $100 \mathrm{ml}$ of yogurt, none of the examined individuals reported abdominal discomfort or changes in stool consistency (Table II).

\section{Discussion}

In the present study, 3 doses of yogurt served without a meal after a fasting period as a single dose were compared. The obtained data suggest that LI subjects can tolerate $100 \mathrm{ml}$ of yogurt (lactose content $4.8 \mathrm{~g}$ ) without clinical symptoms. It seems that a dose of $200 \mathrm{ml}$ of yogurt (lactose content $9.6 \mathrm{~g}$ ) may also be tolerated with minor or no symptoms, while $400 \mathrm{ml}$ (lactose content $19.2 \mathrm{~g}$ ) brought about typical symptoms in all examined LI subjects, and also evoked abnormal BT results in all of them. Despite the fact that $200 \mathrm{ml}$ of yogurt did not cause severe clinical symptoms, the BT results in two subjects were abnormal, with one subject having a borderline BT result (20 ppm), while in all other individuals the hydrogen/methane excretion was significantly higher than in healthy subjects. Ingestion of a dose of $100 \mathrm{ml}$ of yogurt was associated with a borderline rise of $\mathrm{H}_{2}$ production exclusively in one individual. However, in all studied subjects, the production of hydrogen/methane was higher than typically observed in healthy subjects.

Table I. Hydrogen-methane breath test (ppm) after ingestion of 400, 200 and $100 \mathrm{ml}$ of yogurt in 10 lactose intolerant subjects

Tabela I. Wyniki wodorowo-metanowego testu oddechowego (ppm) przeprowadzonego u 10 osób z nietolerancją laktozy po spożyciu 400, 200 i $100 \mathrm{ml} \mathrm{jogurtu}$

\begin{tabular}{|c|c|c|c|c|c|c|c|c|c|c|c|c|}
\hline \multirow[t]{2}{*}{ Yogurt } & & \multicolumn{10}{|c|}{ Time $[\mathrm{min}]$} & \multirow[b]{2}{*}{300} \\
\hline & & 0 & 30 & 60 & 90 & 120 & 150 & 180 & 210 & 240 & 270 & \\
\hline \multirow[t]{2}{*}{$400 \mathrm{ml}$} & Median & 0 & 1 & 1 & 7 & 15 & 22 & 30 & 33 & 31 & 30 & 27 \\
\hline & $1^{\text {st-3rd }}$ quartile & $0-3$ & $0-2$ & $0-5$ & $5-10$ & $15-19$ & $20-23$ & $23-36$ & $27-36$ & $25-35$ & $24-38$ & $22-33$ \\
\hline \multirow[t]{2}{*}{$200 \mathrm{ml}$} & Median & 0 & 1 & $1-5$ & 3 & 6 & 10 & 13 & 15 & 14 & 14 & 12 \\
\hline & $1^{\text {st.-3rd }}$ quartile & $0-2$ & $0-2$ & $1-3$ & $2-5$ & $5-11$ & $7-13$ & $11-15$ & $13-21$ & $12-20$ & $11-19$ & $9-17$ \\
\hline \multirow[t]{2}{*}{$100 \mathrm{ml}$} & Median & 0 & 0.5 & 1.5 & 2.5 & 3 & 4.5 & 5 & 5.5 & 6.5 & 5 & 4.5 \\
\hline & $1^{\text {st-3rd }}$ quartile & $0-1$ & $0-1$ & $0-2$ & $1-3$ & $3-6$ & $3-7$ & $3-8$ & $4-10$ & $4-8$ & $3-7$ & $3-7$ \\
\hline \multicolumn{13}{|c|}{ Statistical significance } \\
\hline \multicolumn{2}{|c|}{$400 \mathrm{ml}$ vs. $200 \mathrm{ml}$ vs. $100 \mathrm{ml}$} & NS & NS & NS & 0.01 & 0.0001 & 0.00001 & 0.00001 & 0.00001 & 0.00001 & 0.00001 & 0.00001 \\
\hline \multicolumn{2}{|c|}{$400 \mathrm{ml}$ vs. $200 \mathrm{ml}$} & NS & NS & NS & NS & 0.013 & 0.024 & 0.041 & 0.023 & 0.022 & 0.046 & 0.065 \\
\hline \multicolumn{2}{|c|}{$400 \mathrm{ml}$ vs. $100 \mathrm{ml}$} & NS & NS & NS & 0.01 & 0.00007 & 0.00001 & 0.00001 & 0.00001 & 0.00001 & 0.00001 & 0.00001 \\
\hline \multicolumn{2}{|c|}{$200 \mathrm{ml}$ vs. $100 \mathrm{ml}$} & NS & NS & NS & NS & NS & NS & 0.076 & NS & NS & 0.076 & 0.058 \\
\hline
\end{tabular}

NS - not significant 
Table II. Clinical symptoms reported after ingestion of 400, 200 or $100 \mathrm{ml}$ of yogurt in 10 lactose intolerant subjects

Tabela II. Objawy kliniczne występujące po spożyciu 400, 200 i 100 ml jogurtu u 10 osób z nietolerancją laktozy

\begin{tabular}{|c|c|c|c|c|c|c|c|c|}
\hline \multirow[t]{2}{*}{ Yogurt } & \multicolumn{2}{|c|}{ Abdominal pain } & \multicolumn{2}{|c|}{ Number of stools } & \multicolumn{2}{|c|}{ Stool consistency } & \multicolumn{2}{|c|}{ Intestinal rumbling } \\
\hline & Median & $1^{\text {st-3rd }}$ quartile & Median & $1^{\text {st-3rd }}$ quartile & Median & $1^{\text {st_-3rd }}$ quartile & Median & $1^{\text {st }} 3^{\text {rd }}$ quartile \\
\hline $400 \mathrm{ml}$ & 1 & $1-1.5$ & 1 & $1-1.5$ & 1 & $0-1$ & 1.5 & $1-2$ \\
\hline $200 \mathrm{ml}$ & 0 & $0-0.5$ & 1 & $0-1$ & 0 & $0-0.5$ & 0.5 & $0-1$ \\
\hline $100 \mathrm{ml}$ & 0 & $0-0$ & 0.5 & $0-1$ & 0 & $0-0$ & 0 & $0-0$ \\
\hline \multicolumn{9}{|l|}{ Statistical significance } \\
\hline $400 \mathrm{ml}$ vs. $200 \mathrm{ml}$ vs. $100 \mathrm{ml}$ & \multicolumn{2}{|r|}{0.07} & \multicolumn{2}{|c|}{0.0018} & \multicolumn{2}{|c|}{0.00001} & \multicolumn{2}{|c|}{0.00001} \\
\hline $400 \mathrm{ml}$ vs. $200 \mathrm{ml}$ & \multicolumn{2}{|r|}{ NS } & \multicolumn{2}{|r|}{ NS } & \multicolumn{2}{|c|}{0.0091} & \multicolumn{2}{|c|}{0.00026} \\
\hline $400 \mathrm{ml}$ vs. $100 \mathrm{ml}$ & \multicolumn{2}{|r|}{ NS } & \multicolumn{2}{|r|}{0.014} & \multicolumn{2}{|c|}{0.00026} & \multicolumn{2}{|c|}{0.00002} \\
\hline $200 \mathrm{ml}$ vs. $100 \mathrm{ml}$ & \multicolumn{2}{|r|}{ NS } & \multicolumn{2}{|r|}{ NS } & \multicolumn{2}{|r|}{ NS } & \multicolumn{2}{|r|}{ NS } \\
\hline
\end{tabular}

NS - not significant

Current dietary recommendations suggest a daily consumption of 3 glasses (about $700 \mathrm{ml}$ ) of fat-free or low-fat milk or equivalent milk products, in order to secure an appropriate calcium intake [12]. That dose (equivalent to about $35 \mathrm{~g}$ of lactose) makes it a recommendation that is impossible for $\mathrm{LI}$ individuals to follow. Discussion concerning determination of the maximum tolerated dose of lactose in $\mathrm{LI}$ persons is still ongoing. Most of the available data arise from the studies based on milk consumption and do not provide an unequivocal answer. The maximum tolerated single dose of lactose suggested by different researchers varies widely from $6 \mathrm{~g}$ to $25 \mathrm{~g}$ [13-15]. It has long been known that lactose tolerance depends on the type of product in which it is ingested and that the lactose in yogurt is better tolerated than that in milk [16]. However, there are no published surveys determining the cut-off point for the lactose dose tolerated by $\mathrm{LI}$ subjects administered in the form of yogurt.

The results of the present study, in which LI subjects were able to clinically tolerate up to $9.6 \mathrm{~g}$ of lactose consumed in the form of yogurt, are consistent with the results of the Alm study [17]. On the other hand, in the present study, the dose of $19.8 \mathrm{~g}$ brought about clinical symptoms. This is not concordant with the findings of Savaiano et al. [7], who documented that $500 \mathrm{ml}$ of yogurt (lactose content $20 \mathrm{~g}$ ) did not cause abdominal distress. A likely explanation may be related to the enrollment criteria; subjects who were classified in the study of Savaiano et al. [7] as "lactose-deficient" were probably LM rather than LI.

Recently introduced genetic testing of the LCT promoter gene is an available and useful method for detection of $L M$ predisposition $[3,18,19]$. In association stud- ies relating genetic polymorphism and eating behavior, decreased consumption of milk in adults with the C/C genotype compared to those with at least one $\mathrm{T}$ allele was consistently reported, suggesting that LM-predisposed individuals avoid milk, presumably to reduce dairy-induced abdominal distress [20, 21]. In order to secure an appropriate calcium and vitamin D intake these individuals are encouraged to consume dairy products, which seems to be justified from a nutritional point of view. However, it has not been proven that such an approach, which would demand a tolerance of mild to moderate abdominal discomfort along with the presence of fermentation gases and osmotic substances, is safe. Therefore, it also raises some doubts whether the clinical symptoms should be the sole determinant of the threshold of dairy product consumption by LM people, especially since it has been shown by Hammer et al. [22] that the subjective symptoms in LM individuals did not correlate with the amount of malabsorbed lactose or with the volume or the rate of gas accumulation per se. It is worth emphasizing that while lactose ingestion may not provoke clinical symptoms itself, it may, however, result in overproduction of gases as evaluated and documented by BT in the present study. It is assumed that the maximum tolerated lactose dose is the one that did not provoke clinical symptoms. Thus, the studies performed to date are based exclusively on a subjective evaluation of intestinal discomfort. Even though, as in the Hertzler et al. [23] and Martini et al. studies [8], the ingested dose of lactose resulted in abnormal hydrogen production documented by BT, the researchers did not refer to that when discussing their results. Bearing in mind that LM subjects do not necessarily manifest symptoms of $\mathrm{LI}$, further surveys assessing the possible 
chronic effects of excessive intestinal fermentation should be considered. The consequences of chronic over-production of gases have not been studied so far, although it has been proven with the use of jejunoscopy that the mucosa of $\mathrm{LI}$ subjects became hyperemic and edematous after lactose exposure [24].

Fermentation is one of the most important functions of the colonic flora and results in the production of volatile fatty acids, lactic acid and gases (hydrogen, carbon dioxide and sometimes methane) [25]. It was shown that diet affects the condition of colonic mucosa predominantly through its effects on microbiota [26]. Disturbances in the bacterial flora and excessive bacterial metabolism may result in the production of cytotoxic substances which promote chronic inflammation or the production of mutagenic compounds. There is evidence that many colonic diseases (pseudomembranous colitis, inflammatory bowel disease, colon cancer) are determined by interactions between the diet and microbiota $[26,27]$ which can be substantially changed by the intensive fermentation occurring in $\mathrm{LI}$ subjects after dairy consumption. On the other hand, it was demonstrated that the administration of viable microbial strains in the form of fermented products can induce a decrease in the concentration of the fecal enzymes (B-glucuronidase, azoreductase, nitroreductase) involved in colonic carcinogenesis $[28,29]$. The net effect of yogurt (milk/dairy product) consumption by LI individuals certainly requires further study.

In conclusion, a subjective observation of clinical symptoms suggests that young adult LI subjects may tolerate up to $200 \mathrm{ml}$ of yogurt served in one meal. However, when considering the objective assessment of lactose malabsorption by breath test, it seems that the dose served per meal definitely should not exceed $100 \mathrm{ml}$.

\section{References}

1. Wilt TJ, Shaukat A, Shamliyan T, et al. Lactose intolerance and health. Evid Rep Technol Assess 2010; 192: 1-410.

2. Heyman MB. Lactose intolerance in infants children and adolescents. Pediatrics 2006; 118: 1279-86.

3. Enattah NS, Sahi T, Savilahti E, et al. Identification of a variant associated with adult-type hypolactasia. Nat Genet 2002; 30: 233-7.

4. Semenza G, Auricchio S, Mantei N. Small-intestinal disaccharidases. In: The metabolic and molecular basis of inherited disease. Scriver CR (ed.). McGraw-Hill, New York 2001; 1623-50.

5. Di Stefano M, Veneto G, Malservisi S, et al. Lactose malabsorption and intolerance and peak bone mass. Gastroenterology 2002; 122: 1793-9.

6. Lovelace HY, Barr SI. Diagnosis symptoms and calcium intakes of individuals with self-reported lactose intolerance. J Am Coll Nutr 2005; 24: 51-7.
7. Savaiano DA, AbouElAnouar A, Smith DE, et al. Lactose malabsorption from yogurt pasteurized yogurt sweet acidophilus milk and cultured milk in lactase-deficient individuals. Am J Clin Nutr 1984; 40: 1219-23.

8. Martini MC, Smith DE, Savaiano DA. Lactose digestion from flavored and frozen yogurts ice milk and ice cream by lactasedeficient persons. Am J Clin Nutr 1987; 46: 636-9.

9. Lerebours E, N'Djitoyap Ndam C, Lavoine A, et al. Yogurt and fermented-then-pasteurized milk: effects of short-term and long-term ingestion on lactose absorption and mucosal lactase activity in lactase-deficient subjects. Am J Clin Nutr 1989; 49: 823-7.

10. USDA National Nutrient Database for Standard Reference Release 21; http://wwwnalusdagov/fnic/foodcomp/Data/SR21/ nutrlist/sr21w301pdf (Accessed 6 November 2011).

11. Mądry E, Lisowska A, Kwiecień J, et al. Adult-type hypolactasia and lactose malabsorption in Poland. Acta Biochim Pol 2010; 57: 585-8.

12. Dietary Guidelines for Americans 2010; http://www.nmpf.org/ washington_watch/nutrition/DietaryGuidelines (Accessed 6 November 2011).

13. Cavalli-Sforza LT, Strata A. Double-blind study on the tolerance of four types of milk in lactose malabsorbers and absorbers. Hum Nutr Clin Nutr 1987; 41: 19-30.

14. Hertzler SR, Huynh BC, Savaiano DA. How much lactose is low lactose? J Am Diet Assoc 1996; 96: 243-6.

15. Jones DV, Latham MC, Kosikowski FV, et al. Symptom response to lactose-reduced milk in lactose-intolerant adults. Am J Clin Nutr 1976; 29: 633-8.

16. Kolars JC, Levitt MD, Aouji M, et al. Yogurt-an autodigesting source of lactose. N Engl J Med 1984; 310: 1-3.

17. Alm L. Effect of fermentation on lactose glucose and galactose content in milk and suitability of fermented milk products for lactose intolerant individuals. J Dairy Sci 1982; 65: 346-52.

18. Enattah N, Valimaki VV, Valimaki MJ, et al. Molecularly defined lactose malabsorption peak bone mass and bone turnover rate in young finnish men. Calcif Tissue Int 2004; 75: 488-93.

19. Mądry E, Fidler E, Walkowiak J. Lactose intolerance - current state of knowledge. Acta Sci Pol Technol Aliment 2010; 9: 343-50.

20. Enattah NS, Sulkava R, Halonen P, et al. Genetic variant of lactase-persistent C/T-13910 is associated with bone fractures in very old age. J Am Geriatr Soc 2005; 53: 79-82.

21. Gugatschka M, Dobnig H, Fahrleitner-Pammer A, et al. Molecularly-defined lactose malabsorption milk consumption and anthropometric differences in adult males. QJM 2005; 98: 857-63.

22. Hammer HF, Petritsch W, Pristautz $\mathrm{H}$, et al. Evaluation of the pathogenesis of flatulence and abdominal cramps in patients with lactose malabsorption. Wien Klin Wochenschr 1996; 108: 175-9.

23. Hertzler SR, Clancy SM. Kefir improves lactose digestion and tolerance in adults with lactose maldigestion. J Am Diet Assoc 2003; 103: 582-7.

24. Banai J, Surján L, Szántó I, et al. Jejunoscopic lactose provocation. Gastroenterol Jpn 1984; 19: 127-30.

25. Marteau P, Pochart P, Flourié B, et al. Effect of chronic ingestion of a fermented dairy product containing Lactobacillus acidophilus and Bifidobacterium bifidum on metabolic activities of the colonic flora in humans. Am J Clin Nutr 1990; 52: 685-8. 
26. O'Keefe SJ. Nutrition and colonic health: the critical role of the microbiota. Curr Opin Gastroenterol 2008; 24: 51-8.

27. Simon GL, Gorbach SL. Intestinal flora in health and disease. Gastroenterology 1984; 86: 174-93.

28. Goldin BR, Swenson L, Dwyer J, et al. Effect of diet and Lactobacillus acidophilus supplements on human fecal bacterial enzymes. J Natl Cancer Inst 1980; 64: 255-61.

29. Goldin BR, Gorbach SL. The effect of milk and lactobacillus feeding on human intestinal bacterial enzyme activity. Am J Clin Nutr 1984; 39: 756-61. 